\title{
Rola teleradioterapii w inwazyjnym raku pęcherza moczowego
}

\author{
Jadwiga Nowak-Sadzikowska, Jerzy Jakubowicz
}

Radykalna cystektomia jest leczeniem z wyboru u chorych na inwazyjnego, naciekającego mięśniówkę właściwą raka pęcherza moczowego. Obok chirurgii teleradioterapia stanowi podstawową metodę radykalnego leczenia chorych na inwazyjnego raka pęcherza moczowego. Skojarzone leczenie zachowawcze: TURB, radioterapia i chemioterapia, pozwala na uzyskanie 5-letnich przeżyć całkowitych, wahających się od 50\% do 63\%, przy zachowaniu u około trzech czwartych chorych prawidłowo funkcjonującego pęcherza. Wyniki radykalnego zachowawczego leczenia miejscowego: TURB z następową samodzielną teleradioterapią są niezadowalające, a 5-letnie przeżycia całkowite wynoszą od $20 \%$ do $40 \%$. Prowadzone są liczne badania kliniczne mające na celu poprawę skuteczności napromieniania chorych na inwazyjnego raka pęcherza moczowego poprzez: podwyższanie całkowitej dawki, modyfikowanie obszaru napromienianego, stosowanie niekonwencjonalnych metod frakcjonacji, stosowanie hipertermii, podawanie środków radiouczulających. Samodzielna teleradioterapia jako leczenie radykalne inwazyjnego raka pęcherza moczowego jest obecnie zalecana jedynie w przypadku chorych niezakwalifikowanych do leczenia operacyjnego lub niewyrażających zgody na operację, równocześnie niekwalifikujących się do leczenia systemowego. Biorąc pod uwagę fakt, że rak pęcherza moczowego jest nowotworem pacjentów w starszym wieku, jak również ciągłe starzenie się naszej populacji, samodzielna radioterapia może stanowić jedyną formę leczenia stwarzającą szansę na wyleczenie z inwazyjnego, naciekającego raka pęcherza moczowego w stosunkowo licznej grupie chorych. Rola uzupełniającej radioterapii w stosunku do radykalnej i częściowej cystektomii wymaga oceny w wielośrodkowych randomizowanych badaniach klinicznych.

\section{Role of external radiation therapy in invasive bladder cancer}

Radical cystectomy is the treatment of choice for patients with muscle-invasive bladder cancer. Radiotherapy, as well as surgery are essential methods of treatment of invasive bladder cancer. Combined modality bladder-sparing treatment can achieve 5-year overall survival rates of 50-63\%, and with some $75 \%$ of surviving patients maintaining their bladder. For local treatment alone, radiation therapy following TURB, has resulted in 5-year survival rates of 20-40\%. Many studies have been performed to improve the results of radiotherapy in the treatment of invasive bladder cancer by escalation of total dose, adoption of altered fractionation, modification of treatment volume, application of hyperthermia or using radiosensitizers. Radical radiotherapy following TURB should be used only in patients who are not surgical candidates or who have refused surgery and are not suitable for chemotherapy. Since bladder cancer is a disease of an elderly and aging population, definitive radiotherapy can be only one possibility for radical treatment for relatively large number of patients with muscle-invasive bladder cancer. Preoperative or postoperative radiotherapy following radical or partial cystectomy need further evaluation in multicenter randomized controlled trials.

Słowa kluczowe: rak pęcherza moczowego, teleradioterapia, leczenie oszczędzające

Key words: bladder cancer, external beam radiotherapy, conservative therapy 


\section{Wstęp}

Rak pęcherza moczowego jest jednym z najczęstszych nowotworów układu moczowego. W województwie małopolskim zachorowania na raka pęcherza moczowego w 2006 r. stanowiły wśród mężczyzn 7\% ogółu wszystkich zachorowań na nowotwory, zaś u kobiet - 1,6\% [1].

Obok chirurgii teleradioterapia stanowi podstawową metodę radykalnego leczenia chorych na inwazyjnego, naciekającego mięśniówkę właściwą raka pęcherza moczowego; jest ona również stosowana jako leczenie uzupełniające (neoadiuwantowe lub adiuwantowe) radykalnej lub częściowej cystektomii.

\section{Radykalne leczenie zachowawcze inwazyjnego, naciekającego mięśniówkę właściwą raka pęcherza moczowego}

Radykalne leczenie operacyjne jest postępowaniem z wyboru u chorych na inwazyjnego raka pęcherza moczowego. Jednakże nie przeprowadzono żadnego prospektywnego randomizowanego badania klinicznego porównującego skuteczność chirurgii i teleradioterapii. Prospektywne randomizowane wieloośrodkowe badanie brytyjskie, rozpoczęte w 2007 roku, porównujące radykalną cystektomię z napromienianiem, a więc leczeniem oszczędzającym narząd u chorych na inwazyjnego raka pęcherza moczowego, zostało przerwane ze względu na bardzo ograniczoną rekrutację: 45 chorych w okresie 30 miesięcy [2].

W leczeniu zachowawczym chorych na inwazyjnego raka pęcherza moczowego stosujemy różne metody: elektroresekcję przezcewkową guza pęcherza (TURB), radioterapię i chemioterapię. Liczne prace opisujące skojarzone leczenie wielodyscyplinarne, wykorzystujące wszystkie wymienione sposoby postępowania, przedstawiają wyniki porównywalne z radykalną cystektomią [3-9]. Skojarzone leczenie zachowawcze:TURB, radioterapia i chemioterapia, pozwala na uzyskanie 5-letnich przeżyć całkowitych, wahających się od 50\% do 63\%, przy zachowaniu u około trzech czwartych chorych prawidłowo funkcjonującego pęcherza. Ratująca cystektomia jest wykonywana w przypadku braku uzyskania całkowitej remisji lub nawrotu po leczeniu zachowawczym. Wyniki leczenia miejscowego:TURB i radioterapii, są gorsze w porównaniu ze skojarzonym leczeniem: TURB, radioterapia i chemioterapia. W związku z tym radykalne leczenie miejscowe stosowane jest tylko u chorych zdyskwalifikowanych z chemioterapii, jednakże uwzględniając fakt występowania raka pęcherza moczowego w grupie osób w starszym wieku, ze współistniejącymi poważnymi schorzeniami, odsetek pacjentów kwalifikujących się do TURB i samodzielnej teleradioterapii jest znaczny.

\section{Radykalne zachowawcze leczenie miejscowe}

Leczenie to polega na maksymalnie radykalnej resekcji guza pęcherza na drodze TURB z następową radioterapią.
Stopień radykalności zabiegu TURB, który jest ściśle skorelowany ze stopniem zawansowania T oraz sposobem wzrostu guza, jest jednym z istotniejszych czynników prognostycznych radykalnego leczenia zachowawczego.

Zastosowanie TURB z następową samodzielną teleradioterapią pozwala na uzyskanie u chorych na inwazyjnego, naciekającego mięśniówkę raka pęcherza moczowego 5-letnich przeżyć całkowitych, wynoszących od $20 \%$ do $40 \%$ i przeżyć specyficznych, wahających się od $31 \%$ do $56,8 \%$ [10-16].

W retrospektywnych badaniach brytyjskich porównujących radykalną cystektomię z radykalną teleradioterapią u chorych na inwazyjnego raka pęcherza moczowego wykazano brak znamiennych różnic w 5-letnich przeżyciach całkowitych, specyficznych i wolnych od nawrotu mimo znamienne starszego wieku chorych napromienianych (średnia wieku 75,3 vs 68,2) [14-15]. Kotwal i wsp., oceniając grupę 169 chorych leczonych w latach 1996-2000, przedstawili 5-letnie przeżycia całkowite, w grupie napromienianej i operowanej, wynoszące odpowiednio 34,6\% i 41,3\% ( $p=0,392$ ) [14]. Porównując chorych leczonych w latach 1996-2000 i 2002-2006, zauważono wzrost średniej wieku chorych napromienianych, przy niezmieniającym się wieku chorych operowanych (75,3 lat vs 78,4 lat w grupie napromienianej i 68,2 lat vs 67,9 lat w grupie operowanej). Aktualnie porównanie wyników leczenia TURB i samodzielnej teleradioterapii z samodzielnym radykalnym leczeniem operacyjnym jest niemożliwe ze względu na szerokie wskazania do zastosowania neodiuwantowego lub adiuwatowego leczenia chemioterapią w skojarzeniu z operacją.

Wyniki leczenia TURB i samodzielnej teleradioterapii są niezadawalające. Prowadzone są liczne badania kliniczne mające na celu poprawę skuteczności napromieniania chorych na inwazyjnego raka pęcherza moczowego poprzez: podwyższanie całkowitej dawki, stosowanie niekonwencjonalnych metod frakcjonacji, kojarzenie tele-i brachyterapii, stosowanie hipertermii, podawanie środków radiouczulających [17-27].

Obszar napromieniany w leczeniu raka pęcherza moczowego nie jest jednoznacznie ustalony, najczęściej obejmowany jest pęcherz moczowy wraz z naciekiem z marginesem ok. 2-3 cm. Wartość napromienia regionalnych węzłów chłonnych, ocenionych jako N0, dawką 40-45 Gy konwencjonalnie frakcjonowaną, jest kontrowersyjna [12, 28-30]. Nie przeprowadzono żadnego prospektywnego randomizowanego badania porównującego napromienianie pęcherza moczowego wraz z regionalnymi węzłami chłonnymi z napromienianiem samego pęcherza moczowego. Publikowane wyniki retrospektywnych analiz oceniających wartość napromieniania węzłów chłonnych w obszarze miednicy $w$ samodzielnej radykalnej radioterapii raka pęcherza moczowego są sprzeczne [28-30].

Jedyne prospektywne badanie kliniczne porównujące napromienianie pęcherza moczowego wraz z regionalnymi 
węzłami chłonnymi z napromienianiem samego pęcherza przeprowadzono w grupie 230 chorych na inwazyjnego raka pęcherza moczowego (T2-T4, N0) leczonych w sposób skojarzony: radioterapia z równoczasową chemioterapią cisplatyną [31]. W obu ramionach badania (radioterapia samego pęcherza moczowego vs pęcherza moczowego i regionalnych węzłów chłonnych) obserwowano porównywalne 5-letnie przeżycia: z zachowanym pęcherzem $57,1 \%$ vs 58,9\%; $p=0,8$, bezobjawowe $46,9 \%$ vs $47,1 \% ; p=0,5$ i całkowite $51 \%$ vs 52,9\%; $p=0,8$. Przy ograniczonym obszarze napromieniania zauważono znamiennie mniejszą toksyczność wczesną leczenia; ogólnie powikłania G3-G4 wynosiły odpowiednio 17,6\% i 13,3\%; $(p=0,05)$, powikłania ze strony przewodu pokarmowego, biegunka G3-G4 - 3,9\% i 2\%; $(p=0,05)$.

W prospektywnym randomizowanym badaniu porównującym samodzielną radioterapię z radiochemioterapią (obszar napromieniany obejmował tylko pęcherz moczowy) rzadko obserwowano izolowany rozsiew do regionalnych węzłów chłonnych, wynoszący odpowiednio 6,7\% i 4,9\% [5].

Ograniczenie obszaru napromienianego do pęcherza moczowego wraz z guzem, przy braku rozsiewu do regionalnych węzłów chłonnych, wydaje się być skutecznym postępowaniem, pozwalającym zmniejszyć toksyczność leczenia przy niskim ryzyku izolowanego rozsiewu do regionalnych węzłów chłonnych.

Głównym organem ograniczającym eskalację dawki promieniowania jest sam pęcherz moczowy, dalsze zmniejszanie terenu napromienianego wysoką dawką do guza pęcherza z marginesem jest przedmiotem badań klinicznych. Wznowa miejscowa obserwowana jest w 75-95\% w obszarze wyjściowego guza, stąd hipoteza, że podwyższanie dawki na guz z marginesem może poprawiać kontrolę miejscową bez zwiększania toksyczności leczenia i w końcowym efekcie przełożyć się na dłuższe przeżycie całkowite.

Przy ograniczeniu dawki całkowitej podawanej na cały pęcherz +/- regionalne węzły chłonne i podwyższenie dawki na obszar guza pęcherza z marginesem obserwowano porównywalne wyniki leczenia przy niższej toksyczności późnej [19, 20, 32-34].

W retrospektywnej analizie obejmującej 229 chorych na inwazyjnego raka pęcherza moczowego napromienianych jednoetapowo na pęcherz moczowy z $2 \mathrm{~cm}$ marginesem w porównaniu z napromienianymi w dwóch etapach: I etap - guz pęcherza z $2 \mathrm{~cm}$ marginesem, II etap - cały pęcherz z $2 \mathrm{~cm}$ marginesem, wykazano znamiennie mniejszą toksyczność późną przy ograniczonym terenie napromienianym, z porównywalną kontrolą miejscową i przeżyciami całkowitymi; redukcja całkowitych powikłań późnych G3-G4 wynosiła 19\% ( $p=0,02)$ [33].

Wstępne wyniki prospektywnego randomizowanego badania porównującego napromienianie dawką całkowitą pęcherza moczowego wraz z naciekiem, z marginesem
$1,5 \mathrm{~cm}$ (108 chorych), z napromienianiem pęcherza moczowego wraz z guzem, $z$ marginesem $1,5 \mathrm{~cm}$ dawką stanowiącą $80 \%$ dawki całkowitej, z następowym podwyższeniem dawki na obszar ograniczony do guza pęcherza z 1,5 cm marginesem (111 chorych), nie wykazały różnic w 2-letnich przeżyciach lokoregionalnych i całkowitych [34]. Toksyczność wczesna i późna, oceniana po roku, była porównywalna w obu ramionach, zaobserwowano znamiennie mniejszą pojemność pęcherza moczowego u chorych napromienianych dawką całkowitą na cały pęcherz moczowy.

Dalsze ograniczanie terenu napromienianego w radykalnym leczeniu inwazyjnego raka pęcherza moczowego do samego guza z marginesem jest możliwe jedynie przy rozpoznaniu jednoogniskowego nacieku i braku współistnienia rozpoznania ca in situ oraz możliwości uzyskania dokładnej powtarzalności obszaru napromienianego poprzez zakładanie znaczników w rzucie guza i/lub stosowanie systemów weryfikacji radioterapii z użyciem obrazowania KV lub CT $w$ trakcie codziennego napromieniania.

W prospektywnym randomizowanym badaniu ograniczenie pola napromienianego do samego guza pęcherza z marginesem (57,5 Gy w 20 frakcjach lub 55 Gy w 16 frakcjach) w porównaniu z całym pęcherzem (52,5 Gy w 20 frakcjach) umożliwiło zwiększenie dawki przy zachowanej kontroli miejscowej i akceptowalnej toksyczności, bez wpływu na przeżycia całkowite [35]. Jednakże należy zauważyć, że w grupie napromienianej jedynie na obszar guza z marginesem obserwowano nawrót nowotworu w pęcherzu, poza terenem napromienianym, u 6 spośród z 89 (7\%) chorych.

Ocena lokalizacji i rozległości nacieku nowotworowego przed radioterapią opiera się na opisie badania cystoskopowego w skojarzeniu z wynikami histopatologicznymi wycinków oraz badaniach obrazowych. Ograniczanie obszaru napromienianego wysoką dawką do guza z marginesem wiąże się z dużym ryzykiem błędu lokalizacji i oceny rozległości nacieku nowotworowego. W retrospektywnej analizie porównującej umiejscowienie i rozległość guza, ocenione przedoperacyjnie i w materiale pooperacyjnym, wykazano niezgodności w 96\% (213/222). W 58\% stwierdzono obecność nacieku inwazyjnego raka pęcherza moczowego w przynajmniej jednej lokalizacji w pęcherzu, nierozpoznanego w badaniach przedoperacyjnych [36]. W $12 \%$ wykazano naciek raka inwazyjnego w zupełnie innej lokalizacji, nieprzylegającej do obszaru opisanego w cystoskopii. Ryzyko niedoszacowania rozpoznania inwazyjnego raka pęcherza moczowego w diagnostyce przedoperacyjnej było znamiennie wyższe przy jednoogniskowym nacieku w porównaniu ze zmianami wieloogniskowymi $(p=0,01)$ [37].

Uwzględniając ryzyko błędu lokalizacyjnego guza oraz ryzyko błędu związanego z powtarzalnością obszaru napromienianego $w$ trakcie radioterapii, przy nieznamiennej różnicy w toksyczności leczenia wynikającej z ograniczania z terenu napromienianego, radioterapia całego pęcherza 
moczowego wraz z naciekiem z marginesem, z ewentualnym podwyższeniem dawki na guz, pozostaje standardem postepowania.

W retrospektywnych badaniach oceniających dawkę całkowitą wykazano zależność dawka - efekt [12, 13, 22, $24,26,27]$. Przy zastosowaniu dawki poniżej 60 Gy obserwowano gorsze wyniki leczenia. Badanie Pollacka i wsp. sugeruje większą skuteczność napromieniania chorych na raka pęcherza moczowego T2 i T3 dawką całkowitą $\geq 70$ Gy ( $p=0,07$ ) [33]. W metaanalizie oceniającej 15 badań wykorzystujących w radykalnym leczeniu raka pęcherza moczowego różne schematy frakcjonacji i dawki całkowite (w pięciu badaniach skojarzenie tele- i brachyterapii) wykazano zależność pomiędzy dawką całkowitą a kontrolą miejscową, wzrost dawki całkowitej o 10 Gy poprawiał wyleczalność miejscową o czynnik 1,44-1,47 (95\% Cl, 1,23-1,70) [24]. Zalecana dawka całkowita konwencjonalnie frakcjonowana waha się od 60 do $66 \mathrm{~Gy}$.

Stosowane obecnie nowoczesne techniki napromieniania: konformalna radioterapia (CTR), radioterapia z wykorzystaniem intensywnej modulacji dawki (IMRT), radioterapia adaptacyjna, zakładanie znaczników do pęcherza w rzucie guza, ograniczanie obszaru napromieniania poprzez stosowanie systemów weryfikacji leczenia umożliwiają dalszą eskalację dawki przy zachowaniu akceptowalnej toksyczności leczenia.

Główną przyczyną niepowodzenia konwencjonalnej radioterapii w leczeniu inwazyjnego raka pęcherza moczowego jest niewyleczenie miejscowe lub wznowa u 40-60\% chorych, obserwowana w okresie od roku do 2 lat, co wskazuje na szybką proliferację komórek klonogennych [10-12].

Podejmowane są różne próby przełamania tego niekorzystnego efektu poprzez skrócenie całkowitego czasu leczenia, przy zastosowaniu niekonwencjonalnej frakcjonacji dawki promieniowania. Jednakże rola całkowitego czasu leczenia w leczeniu raka pęcherza moczowego stanowi ciągle nierozwiązany problem [22-26]. Niektórzy autorzy sugerują niekorzystny wpływ wydłużonego czasu leczenia, inni uważają, że wpływ całkowitego czasu leczenia na jego wynik jest ograniczony, lub nawet nie obserwują znamiennych statystycznie zależności.

W Wielkiej Brytanii szeroko rozpowszechnione jest zastosowanie w radykalnym leczeniu inwazyjnego raka pęcherza moczowego hipofrakcjonacji; dawka całkowita wynosi 52,5-57,5 Gy w 20 frakcjach, z dawką frakcyjną wahającą się od 2,6-2,9 Gy [5, 34, 35, 37]. Dawka 55 Gy w 20 frakcjach jest równoważna biologicznie dawce 64 Gy w 32 frakcjach. Toksyczność, zarówno wczesna, jak i późna ww. schematów hypofrakcjonacji jest porównywalna z konwencjonalną frakcjonacją radioterapii.

Zastosowanie przyspieszonej frakcjonacji techniką concomitant boost w leczeniu inwazyjnego raka pęcherza moczowego pozwala na uzyskanie 3-letnich przeżyć lo- koregionalnych i całkowitych wynoszących odpowiednio 56-64\% i 36-46\% [19, 20, 32]. Obserwowana toksyczność wczesna i późna jest akceptowalna.

Jednakże w prospektywnym randomizowanym badaniu klinicznym Horwich i wsp. nie wykazali poprawy wyników w grupie chorych na inwazyjnego raka pęcherza moczowego T2 i T3 leczonych napromienianiem przyspieszoną frakcjonacją (60,8 Gy w 32 frakcjach dwa razy dziennie) w porównaniu z klasyczną frakcjonacją (64 Gy w 32 frakcjach) [25]. Obserwowano większą toksyczność wczesną ze strony jelit w ramieniu z niekonwencjonalną frakcjonacją, powikłania G2-G3 w skali RTOG wynosiły odpowiednio $44 \%$ vs $26 \%$, $p=0,001$. Toksyczność wczesna i późna ze strony pęcherza moczowego w obu ramionach była porównywalna.

Podejmowane są również próby stosowania w leczeniu inwazyjnego raka pęcherza moczowego hiperfracjonacji polegającej na podawaniu większej ilości niższych dawek frakcyjnych, w całkowitym czasie leczenia zbliżonym do konwencjonalnej frakcjonacji, co skutkuje wzrostem dawki całkowitej, bez ryzyka wzrostu powikłań późnych. W metaanalizie oceniającej prospektywne randomizowane badania porównujące klasyczne frakcjonowanie $z$ hiperfracjonowaniem $\mathrm{w}$ radioterapii raka pęcherza moczowego wykazano znamienną poprawę kontroli miejscowej i przeżycia całkowitego na korzyść hiperfrakcjonowania [38].

Zastosowanie niekonwencjonalnej frakcjonacji, w formie hypofrakcjonacji czy przyspieszonej frakcjonacji concomitant boost, zwłaszcza przy uwzględnieniu grupy chorych leczonych samodzielną radioterapią — starszych, w gorszym stanie ogólnym, z poważnymi schorzeniami współistniejącymi, stanowi korzystną opcję leczenia, pozwalającą podać wyższą dawkę w skróconym całkowitym czasie terapii, przy toksyczności porównywalnej z klasyczną frakcjonacją.

Podejmowane są próby zwiększenia skuteczności radioterapii poprzez skojarzenie jej z hipertermią. Van der Zee i wsp. w prospektywnym randomizowanym badaniu klinicznym wykazali, że głęboka miejscowa hipertermia wraz z radioterapią znamiennie zwiększają odsetek całkowitych remisji $(73 \%$ vs $51 \% \mathrm{p}=0,01)$ w porównaniu z samodzielną radioterapią u chorych na inwazyjnego raka pęcherza moczowego T2-T4 [39].

Ocena roli hipertermii i jej skuteczność w zachowawczym leczeniu raka pęcherza moczowego wymaga dalszych badań.

Niedotlenowanie komórek nowotworowych jest uznanym niekorzystnym czynnikiem prognostycznym w leczeniu napromienianiem. Odsetek komórek hipoksycznych w urotelialnym raku pęcherza oceniany jest na poziomie ok. $10 \%$. W celu przełamania niekorzystnego efektu hipoksji podejmowane są badania kojarzące radioterapię z karbogenem $\left(95 \% \mathrm{O}_{2}+5 \% \mathrm{CO}_{2}\right)$ i nikotynamidem $[17,40]$.

W grupie 133 chorych na raka pęcherza moczowego T1 G3, T2-T4a, N0, M0 skojarzenie radioterapii z karboge- 
nem i nikotynamidem znamiennie poprawiło przeżycia całkowite, redukując ryzyko zgonu o 14\% ( $p=0,04)$. Nie obserwowano różnic toksyczności późnej ze strony układu moczowego i pokarmowego w obu grupach [17].

Zastosowanie przyspieszonej frakcjonacji łącznie z karbogenem i nikotynamidem (ARCON - accelereted radiotherapy combined with carbogen and nicotinamide) ma na celu przełamanie repopulacji komórek klonogennych guza i hipoksji. Doświadczenia z podawaniem karbogenu i nikotynamidu z hypofrakcjonowaną radioterapią (55 Gy w 20 frakcjach) pozwoliły na uzyskanie 5-i 10-letniego przeżycia całkowitego wynoszącego odpowiednio 35\% i 27\% oraz 5- i 10-letniego przeżycia specyficznego, wynoszącego 55\% i 47\% [40] . Toksyczność wczesna i późna ARCON i radioterapii konwencjonalnie frakcjonowanej w skojarzeniu z karbonem i nikotynamidem były porównywalne.

Ocena wpływu modyfikacji niedotlenienia komórek raka urotelialnego na wyniki leczenia wymaga dalszych badań klinicznych.

\section{Neoadiuwantowe leczenie napromienianiem}

Prowadzone od lat 60 . badania nad zastosowaniem przedoperacyjnej radioterapii nie pozwoliły jednoznaczne wykazać jej istotnego wpływu na wyniki leczenia [41, 42]. Jedynie w podgrupie z zaawansowaniem T3b, po napromienianiu przed radykalną cystektomią dawką całkowitą ok. 50 Gy, klasycznie frakcjonowaną, obserwowano istotną poprawę kontroli miejscowej, bez znamiennego wpływu na przeżycia całkowite i przeżycia bez przerzutów odległych [41].

Ostatecznie metaanaliza pięciu randomizowanych badań klinicznych potwierdziła brak znamiennych statystycznie różnic w przeżyciach przy stosowaniu przedoperacyjnej radioterapii z następową cystektomią w porównaniu z samodzielną cystektomią [43].

W badaniu oceniającym 25 chorych na raka pęcherza moczowego T1-T3, po zabiegu TURB, podawano napromienianie 25 Gy w 5 frakcjach, z następową częściową cystektomią i ze śródoperacyjnym podaniem dopęcherzowo thiotepy przed usunięciem guza oraz z pooperacyjnym leczeniem dopęcherzowym BCG (Bacillus Calmette-Guerin). Przy zastosowanym schemacie leczenia uzyskano 5-letnie przeżycia całkowite, specyficzne i wolne od nawrotu, wynoszące odpowiednio 70\%, 84\%, 64\% [44].

Przedoperacyjna radioterapia lub radiochemioterapia przed zabiegiem radykalnej lub częściowej cystektomii pozostaje postępowaniem niestandardowym, a leczenie tego typu powinno być prowadzone wyłącznie w ramach badań klinicznych.

\section{Adiuwantowe leczenie napromienianiem}

Doniesienia dotyczące uzupełniającej radioterapii po radykalnej cystektomii są rzadkie i ocena ich skuteczności i toksyczności wymaga dalszych prospektywnych badań klinicznych. Koncepcja stosowania uzupełniającego leczenia napromienianiem wiąże się z wysokim ryzykiem niepowodzenia lokoregionalnego po samodzielnym radykalnym leczeniu chirurgicznym lub skojarzonym z chemioterapią, sięgającym przy rozpoznaniu $\geq$ pT3 do $23-42 \%$ $[45,46]$.

W randomizowanym badaniu klinicznym zastosowanie pooperacyjnej radioterapii (3 frakcje dziennie po 1,25 Gy każda, podawane co 3 godziny, dawka całkowita 37,5 Gy w całkowitym czasie leczenia 12 dni; lub 50 Gy w 25 frakcjach, konwencjonalnie frakcjonowane) w porównaniu z samodzielną cystektomią u chorych z miejscowo zawansowanym rakiem pęcherza moczowego znamiennie poprawiło zarówno kontrolę miejscową, jak i przeżycia bezobjawowe [47]. W ocenianej grupie $20 \%$ stanowili chorzy z rozpoznaniem raka urotelialnego (pozostali chorzy — raka płaskonabłonkowego i raka gruczołowego), jednakże poprawę wyników obserwowano niezależnie od utkania histologicznego.

W retrospektywnej ocenie Cozzariniego i wsp. u chorych na urotelialnego raka pęcherza moczowego, T2-T4a, uzyskano zbliżone wyniki [48].

Stosowanie uzupełniającej radioterapii po cystektomii wiąże się z dużym ryzykiem powikłań, głównie ze strony przewodu pokarmowego, sięgającym od $12 \%$ do $40 \%$ [47-48]. Rozwój technik radioterapii i możliwość większego oszczędzenia tkanek zdrowych powinien przełożyć się na zmniejszenie toksyczności uzupełniającego leczenia.

Uzupełniające leczenie napromienianiem po radykalnej cystektomii może być rozważane w przypadku $\geq$ pT3, dodatniego marginesu, pN+, G3; zalecana dawka całkowita waha się od 40 do $50 \mathrm{~Gy}$, konwencjonalnie frakcjonowana.

Wskazania do uzupełniającej radioterapii lub chemioradioterapii w oparciu o cisplatynę po zabiegu częściowej cystektomii są identyczne ze wskazaniami jak po radykalnej cystektomii.

Ocena roli uzupełniającej radioterapii po zabiegach radykalnej lub częściowej cystektomii wymaga również wieloośrodkowych prospektywnych badań klinicznych.

\section{Podsumowanie}

Samodzielna teleradioterapia jako leczenie radykalne chorych na inwazyjnego raka pęcherza moczowego jest obecnie zalecana jedynie w przypadku chorych niezakwalifikowanych do leczenia operacyjnego lub niewyrażających zgody na operację, równocześnie niekwalifikujących się do leczenia systemowego. Biorąc pod uwagę fakt, że rak pęcherza moczowego jest nowotworem pacjentów w starszym wieku, jak również ciągłe starzenie się naszej populacji, samodzielna radioterapia może stanowić jedyną formę leczenia stwarzającą szansę na wyleczenie $z$ inwazyjnego naciekającego raka pęcherza moczowego w stosunkowo licznej grupie chorych. 
Rola uzupełniającej radioterapii w stosunku do radykalnej i częściowej cystektomii wymaga oceny w wielośrodkowych randomizowanych badaniach klinicznych.

\section{Konflikt interesu: nie zgłoszono}

\section{Dr n. med. Jadwiga Nowak-Sadzikowska}

Klinika Onkologii Oddział Nowotworów Jamy Brzusznej

Centrum Onkologii — Instytut im. Marii Skłodowskiej-Curie

Oddział w Krakowie

ul. Garncarska 11,31-115 Kraków

e-mail:z5sadzik@cyfronet.krakow.pl

Otrzymano: 8 lipca 2013 r.

Przyjęto do druku: 7 października 2013 r.

\section{Piśmiennictwo}

1. Rachtan J, Sokołowski A, Geleta M i wsp. Nowotwory złośliwe w województwie małopolskim w 2006 roku. Kraków: Centrum Onkologii Instytut im. Marii Skłodowskiej-Curie, Oddział w Krakowie; 2008: 31-35.

2. Huddart RA, Hall EE, Lewis R o wsp. Life and death of SPARE (Selective Bladder Preservation Against Radical Excision): reflections on why the spare trial closed. BJU Int 2010; 106: 753-755.

3. Rödel C, Grabenbauer GG, Kühn Ri wsp. Combined-modality treatment and selective organ preservation in invasive bladder cancer: long-term results. J Clin Oncol 2002; 20: 3061-3071.

4. Perdona S, Autorino R, Damiano R i wsp. Bladder-sparing, combined-modality approach for muscle-invasive bladder cancer. Cancer 2008; 112: 75-83

5. James ND, Hussain SA, Hall E i wsp. Radiotherapy with or without chemotherapy in muscle-invasive bladder cancer. N Engl J Med 2012; 366: 1477-1488.

6. Weiss C, Engehausen DG, Krause FS i wsp. Radiochemotherapy with cisplatin and 5-fluorouracil after transurethral surgery in patients with bladder cancer. Int J Radiat Oncol Biol Phys 2007; 68: 1072-1080.

7. George L, Bladou F, Bardou VJ i wsp. Clinical outcome in patients with locally advanced bladder carcinoma treated with conservative multimodality therapy. Urology 2004; 64: 488-493.

8. Efstathiou JA, Spiegel DY, Shipley WU i wsp. Long-term outcomes of selective bladder preservation by combined-modality therapy for invasive bladder cancer: the MGH experience. Eur Urol 2012;61: 705-711.

9. Kaufman DS, Winter KA, Shipley WU i wsp. Phase RTOG I-II study (99-06) of patients with muscle-invasive bladder cancer undergoing transurethral surgery, paclitaxel, cisplatin, and twice-daily radiotherapy followed by selective bladder preservation or radical cystectomy and adjuvant chemotherapy. Urology 2009; 73: 833-837.

10. Mameghan $\mathrm{H}$, Fisher R, Mameghan J i wsp. Analysis of failure following definitive radioterapy for invasive transitional cell carcinoma of the bladder. Int J Radiat Oncol Biol Phys 1995; 31: 247-254.

11. Jahnson S, Pedersen J, Westman G i wsp. Bladder carcinoma - a 20-year review of radical irradiation therapy. Radiother Oncol 1991;22: 111-117.

12. Senegeløv $\mathrm{L}$, von der Maase H. Radiotherapy in bladder cancer. Radiother Oncol 1999; 52: 1-4.

13. Skołyszewski J, Reinnfuss $M$, Weiss M. Radical external beam radiotherapy of urinary bladder carcinoma. Acta Oncol 1994; 33: 561-565.

14. Kotwal S, Choudhury A, Johnston C i wsp. Similar treatment outcomes for radical cystectomy and radical radiotherapy in invasive bladder cancer treated at a United Kingdom Specialist Treatment Center. Int J Radiat Oncol Biol Phys 2008; 70: 456-463.

15. Chahal R, Sundaram SK, Iddenden R i wsp. A study of the morbidity, mortality and long-term survival following radical cystectomy and radical radiotherapy in the treatment of invasive bladder cancer in Yorkshire. European Urology 2003; 43: 246-257.

16. Langsenlehner T, Döller C, Quehenberger F i wsp. Treatment results of radiation therapy for muscle-invasive bladder cancer. Strahlenther Oncol 2010; 186: 203-209.

17. Hoskin P, Rojas A, Bentzen SM. Radiotherapy with concurrent carbogen and nicotinamide in bladder cancer carcinoma. J Clin Oncol 2010; 28 : 4912-4918.

18. Moonen $L$, van der Voet $H$, Horenblas $\mathrm{S} i$ wsp. A feasibility study of accelerated fractionation in radiotherapy of carcinoma of the urinary bladder. Int J Radiat Oncol Biol Phys 1997; 37: 537-542.

19. Pos FJ, van Tienhoven G, Hulshof MC. Concomitant boost radiotherapy for muscle invasive bladder cancer. Radiother Oncol 2003; 68: 75-80.

20. Yavuz AA, Yavuz MN, Ozgur GK i wsp: Accelerated superfractionated radiotherapy with concomitant boost for invasive bladder cancer. Int J Radiat Oncol Biol Phys 2003; 56: 734-745.

21. van der Steen-Banasik EM, Visser AG, Reinders JG i wsp. Saving bladders with brachyterapy: implantation technique and results. Int J Radiat Oncol Biol Phys 2002; 53: 622-629.
22. Moonen $\mathrm{L}$, vd Voet $\mathrm{H}$, de Nijs $\mathrm{R}$ i wsp. Muscle-invasive bladder cancer treated with external beam radiation: influence of total dose, overall treatment time, and treatment interruption on local control. Int J Radiat Oncol Biol Phys 1998; 42: 525-530.

23. De Neve W, Lybeert MLM, Goor C i wsp. Radiotherapy for T2 and T3 carcinoma of bladder: the influence of overall treatment time. Radiother Oncol 1995; 36: 183-188.

24. Pos FJ, Hart G, Schneider C i wsp. Radical radiotherapy for invasive bladder cancer: What dose and fractionation schedule to choose? Int $J$ Radiat Oncol Biol Phys 2006; 64: 1168-1173.

25. Horwich A, Dearnaley D, Huddart R i wsp. A randomized trial of accelerated radiotherapy for localised invasive bladder cancer. Radiother Oncol 2005; 75: 34-43.

26. Majewski W, Maciejewski B, Majewski S i wsp. Clinical radiobiology of stage T2-T3 bladder cancer. Int J Radiat Oncol Biol Phys 2004; 60:60-70.

27. Pollack A, Zagars GK, Swanson DA. Muscle-invasive bladder cancer treated with external beam: Prognostic factors. Int J Radiat Oncol Biol Phys 1994; 30: 267-277.

28. Tait DM, Nauhum AE, Rigby i wsp. Conformal radiotherapy of the pelvis: assessment of acute toxicity. Radiother Oncol 1993; 29: 117-126.

29. Fish JC Davidson Fayos JV. Carcinoma of the urinary baldder. Influence of dose and volume irradiated on survival. Radiology 1976; 118: 179-182.

30. Davidson SE, Symonds RP, Snee MP i wsp. Assesment of factors influencing the outcome of radiotherapy for bladder cancer. Br J Urol 1990; 66: 288-293.

31. Tunio MA, Hashmi A, Qayyum A i wsp. Whole-pelvis or bladder-only chemoradiation for lymph node-negative invasive bladder cancer: single-institution experience. Int J Radiat Oncol Biol Phys 2012; 82: e457-462.

32. Piet AH, Hulshof MC, Pieters BR i wsp. Clinical results of a concomitant boost radiotherapy technique for muscle-invasive bladder cancer. Strahlenther Onkol 2008; 184: 313-318.

33. Mangar SA, Foo K, Norman A i wsp. Evaluating the effect of reducing the high-dose volume on the toxicity of radiotherapy in the treatment of bladder cancer. Clin Oncol 2006; 18: 466-473.

34. Huddart RA, James D, Adab F i wsp. BC2001: A multicenter phase III randomized trial of standard versus reduced volume radiotherapy for muscule invasive bladder cancer (ISCRTN:68324339). J Clin Oncol 2009; 27: 15 s (suppl; abstr. 5022).

35. Covan RA, McBain CA, Ryder WD i wsp. Radiotherapy for muscle-invasive carcinoma of the bladder: results of a randomized trial comparing conventional whole bladder with dose-escalated partial bladder radiotherapy. Int J Radiat Oncol Biol Phys 2004; 59: 197-207.

36. Goldsmith B, Tucker K, Conway RG i wsp. Discordance between preoperative and postoperative bladder cancer location: implications for partial-bladder radiation. Int J Radiation Oncol Biol Phys 2013; 85: 707-713.

37. Muren LP, Redpath AT, McLaren DB. Treatment margins and treatment fractionation in conformal radiotherapy of muscle-invading urinary bladder cancer. Radiother Oncol 2004; 71: 65-71.

38. Stuschke M, Thames HD. Hyperfractionated radiotherapy of human tumors: overview of the randomized clinical trials. Int J Radiat Oncol Bio Phys 1997; 37: 259-267.

39. van der Zee J, Gonzalez D, van Rhoon GC i wsp. Comparison of radiotherapy alone with radiotherapy plus hyperthermia in locally advanced pelvic tumours: a prospective, randomized, multicentre trial. Dutch Deep Hyperthermia Group. Lancet 2000; 355: 1119-1125.

40. Hoskin P, Rojas A, Saunders M. Accelereted radiotherapy, carbogen, and nicotinamide (ARCON) in the treatment of advanced bladder cancer: mature results of a phase II nonrandomized study. Int J Radiat Oncol Biol Phys 2009; 73: 1425-1431.

41. Cole CJ, Pollack A, Zagars GK i wsp. Local control of muscle-invasive bladder cancer: preoperative radiotherapy and cystectomy versus cystectomy alone. Int J Radiat Oncol Biol Phys 1995; 32: 331-340.

42. Bloom HJG, Hendry WF, Wallance DM i wsp. Treatment of T3 bladder cancer: controlled trial of preoperative radiotherapy and radical cystectomy versus radical radiotherapy. Br J Urol 1982; 54: 136-151.

43. Huncharek M, Muscat J, Geschwind JF. Planned preoperative radiation therapy in muscle invasive bladder cancer: results of a meta-analysis. Anticancer Res 1998; 18: 1931-1934.

44. Smaldone MC, Jacobs BL, Smaldone AM i wsp. Long-term results of selective partial cystectomy for invasive urothelial bladder carcinoma. Urology 2008; 72: 613-616.

45. Herr HW, Faulkner JR, Grossman HB i wsp. Surgical factors influence bladder cancer outcomes: a cooperative group report. J Clin Oncol 2004; 22: 2781-2789.

46. Bauman BC, Guzzo TJ, He J i wsp. A novel risk stratification to predict local-regional failures in urothelial carcinoma of the bladder after radical cystectomy. Int J Radiat Oncol Biol Phys 2013; 85: 81-88.

47. Zaghloul MS, Awwad HK, Akoush HH i wsp. Postoperative radiotherapy of carcinoma in bilharzial bladder: improved disease free survival through improving local control. Int J Radiat Oncol Biol Phys 1992; 23: 511-517.

48. Cozzarini C, Pellegrini D, Fallini M i wsp. 144 Reappraisal of the role of adjuvant radiotherapy in muscle-invasive transitional cell carcinoma of the bladder. Int J Radiat Oncol Biol Phys 1999; 45 (Suppl): 221-222. 